\author{
С.С. Дроздов ${ }^{1}$, О.Б. Леонтьєв ${ }^{2}$, М.В. Науменко ${ }^{2}$ \\ ${ }^{1}$ Командування Повітряних Сил Збройних Сил Украӥни, Вінниия \\ ${ }^{2}$ Харківський наџіональний університет Повітряних Сил ім. І. Кожедуба, Харків
}

\title{
МЕТОДИЧНИЙ ПІДХІД ДО РОЗВ'ЯЗУВАННЯ МАТЕМАТИЧНОЇ ЗАДАЧІ СИНТЕЗУ РАЦІОНАЛЬНОЇ ПРОГРАМИ РОЗВИТКУ СИСТЕМИ ОЗБРОЄННЯ ТАКТИЧНОÏ АВІАЦІЇ НА ОСНОВІ КРИТЕРІЮ МІНІМІЗАЦІЇ ФІНАНСОВИХ ВИТРАТ ЗА УМОВИ ДОСЯГНЕННЯ НЕОБХІДНИХ БОЙОВИХ СПРОМОЖНОСТЕЙ
}

\begin{abstract}
Запропоновано методичний підхід до розв'язання математичної задачі синтезу раціональної програми розвитку системи озброєння та військової техніки (ОВТ) тактичної авіації (ТА), постановку якої здійснено у зворотній формі при виборі за критерій раціональності програми, досягнення заданого необхідного рівня спроможностей частинами $і$ підрозділами тактичної авіації в межах заданого проміжку часу при мінімально потрібних обсягах фінансових витрат. Задачу синтезу програми зведено до канонічної форми пошуку умовного мінімуму цілььової функції відомими методами багатокрокового програмування. Обгрунтовано введення додаткових обмежень, пов'язаних, по-перше, із можливостями серійного виготовлення нових літаків авіаџійною промисловістю, по-друге, необхідністю закупівлі достатньої кількості літаків на кожному інтервалі періоду планування, для забезпечення освоєння нової техніки особовим складом та доведення частин $і$ підрозділів тактичної авіації до заданого рівня бойової готовності.
\end{abstract}

Ключові слова: планування на основі спроможностей, критерії раціональності, оптимізація, програма розвитку, система озброєння тактичної авіації.

\section{Вступ}

Постановка проблеми. Впровадження нових підходів у оборонне планування, яке визначено однією з стратегічних цілей оборонної реформи в Україні (стратегічна ціль № 2), передбачає переведення системи оборонного планування на планування на основі спроможностей [1-4]. Застосування такого виду планування $є$ більш ефективнішим у разі, якщо проект оборонного бюджету надаватиметься законодавчому органу в супроводі адекватного опису оборонних програм разом зі звітом про стан їх виконання [4]. Планування на основі спроможностей являє собою один із методів оборонного планування, особливістю якого є розвиток спроможностей збройних сил (сил оборони) для ефективної протидії загрозам і ризикам як військового, так i невійськового характеру з урахуванням імовірних сценаріїв розвитку кризових ситуацій на довгострокову перспективу (зазвичай на 10-15 років). Даний метод є основним в країнах-членах НАТО [4-5].

Перехід до планування на основі спроможностей потребує вирішення низки проблемних питань, одним з яких є розробка методик переведення спроможностей у кількісно-якісні показники, передусім для планування формування відповідних організаційних структур [4].

3 огляду на анонсоване переозброєння тактич- ної авіації Повітряних Сил (ПС) Збройних Сил (3С) України, що відображено у Візії Повітряних Сил 2035 року [22], створення методик оцінювання можливих варіантів обрису перспективної тактичної авіації ПС ЗС України, і що не менш важливе - синтезу раціональних програм його досягнення, є вкрай актуальним.

Аналіз останніх досліджень і публікацій. Як свідчить огляд доступних джерел інформації [6-14], в існуючих методичних підходах, що застосовуються на етапі формуванні програм і планів розвитку тактичної авіації, зазвичай робиться акцент на оцінювання раціональності іï кількісно-якісного складу, який має бути досягнутий наприкінці терміну планування. Більшість 3 відомих методичних підходів грунтується на використанні експертних методів оцінювання або проведенні SWOT аналізу як оперативного середовища і варіантів побудови відповідної системи озброєння, так і перспектив реалізації програмних і планових заходів щодо розвитку систем ОВТ, наприклад, [7-11]. Такі підходи, нажаль, не дають можливості отримання кількісної оцінки ступеню впливу варіанту програми на набуття необхідних спроможностей військами, яких буде переозброєно новим ОВТ. Також відповідь на питання щодо можливості реалізації розроблених варіантів програм за ресурсними та часовими показниками повинна бути наданою ще до початку оцінювання 
варіантів, тобто ще на етапі генерації альтернатив. Внаслідок цього за результатами такого аналізу неможливо отримати кількісного оцінювання раціональності програм розвитку озброєння, перш за все, у фінансовому вираженні й із врахуванням забезпечення набуття необхідного рівня спроможностей для виконання завдань за визначеними сценаріями застосування сил оборони на заданій глибині планування.

Решта наукових публікацій останнього періоду, що присвячені аналізу можливості виконання програм та управління ними на проміжних етапах, такі як, наприклад [15-16], взагалі передбачають, що програма вже синтезована та не стосуються питань саме синтезу раціональних програм розвитку системи озброєння.

В роботі [12] здійснено спробу формалізації задачі синтезу програм розвитку системи ОВТ виду (роду) військ, на прикладі системи озброєння тактичної авіації. В цій роботі викладено лише тільки загальний методичний підхід та оцінена можливість синтезу програм розвитку ОВТ тактичної авіації за рахунок формалізації залежності іiі спроможності від параметрів іiі системи озброєння методом бойових потенціалів у вигляді постановки зворотної математичної задачі оптимізації, а питання самої методики деталізації постановки й розв'язування задачі не розкрито. Подальшому розвитку такого методичного підходу присвячені роботи [17-18]. В цих роботах розглянуті можливі види критеріїв раціональності програм розвитку системи озброєння тактичної авіації, які можуть бути застосовані при вирішенні практичних задач синтезу раціональних програм при виборі різних стратегій, розроблено систему формалізованих критеріїв раціональності програм оновлення парку літальних апаратів тактичної авіації ПС 3С України на довгостроковій перспективі. Ці критерії відносяться до типу критеріїв “ефективність - вартість - час", які грунтуються на використанні методу бойових потенціалів та системному врахуванні зміни за часом кількісних показників бойових спроможностей системи озброєння тактичної авіації, динаміки зміни оперативного середовища та результатів прогнозу економічної спроможності держави із ресурсного забезпечення розвитку системи озброєння авіації на всій глибині планування. В якості одного 3 таких формалізованих критеріїв $є$ той, що визначає раціональним такий варіант програми, коли в заданий час (наприкінці термінів планування) програма дозволяє переозброїти тактичну авіацію новими бойовими літаками з набуттям необхідних спроможностей за всіма покладеними бойовими завданнями за всіма сценаріями застосування при мінімально можливому обсягу витрат ресурсів. Саме розробці самої методики розв'язування такої математичної задачі синтезу анонсовано спрямованість подальших досліджень авторів.
Таким чином, метою статті $\epsilon$ розробка методичного підходу до розв'язування математичної задачі синтезу раціональної програми розвитку системи озброєння та військової техніки тактичної авіації Повітряних Сил Збройних Сил України за критерієм мінімізації фінансових витрат за умови досягнення необхідного рівня спроможностей.

\section{Виклад основного матеріалу}

Математична постановка оптимізаційної задачі синтезу програми оновлення бойової авіаційної техніки, яка передбачає поступове нарощування спроможностей угруповань авіації Повітряних Сил Збройних Сил України і доведення їх до необхідного рівня у виконанні завдань за визначеними сценаріями не пізніше заданого строку при мінімальному обсязі витрат на закупівлю нових літаків. У формалізованому виді така задача, без урахування будьяких додаткових обмежень на кількість літаків кожного альтернативного типу, може бути записаною як [18]:

$$
\left\{\begin{array}{l}
\int_{t_{0}}^{T_{\text {зад }}} \sum_{j=1}^{n} K_{\text {БПij }} \sum_{r=1}^{m} \delta_{i j r} \dot{X}_{r j}(t) d t \geq \Delta P_{i}\left(T_{\text {зад }}\right), \forall i=1, m ; \\
S=\int_{t_{0}}^{T_{\text {зад }}^{i}} \sum_{j=1}^{n} C_{1 j} \sum_{r=1}^{m} \dot{X}_{r j}(t) d t \rightarrow \mathrm{min} ; \\
T_{\text {гот } i}(t) \leq T_{\text {зад }},
\end{array}\right.
$$

де $n$ - кількість типів літальних апаратів, що можуть входити до складу перспективного авіаційного угруповання ПС Збройних Сил України;

$m$ - кількість бойових завдань із сукупності завдань, що визначені до виконання авіаційним угрупованням по всіх можливих сценаріях застосування тактичної авіації Повітряних Сил ЗС України;

$K_{\text {БПіј }}$ - значення коефіцієнту бойового потенціалу у вирішенні $i$-го завдання зразком $j$-го типу;

$\delta_{i j r}$ - символ, який характеризує можливість залучення засобів $j$-го типу до виконання $i$-го бойового завдання та інших бойових завдань із сукупності $m$ завдань водночас у відповідності до визначеної структури бойового потенціалу авіаційного угруповання $\left(\delta_{i j r}=1-\right.$ при можливості одним й тим же засобом $j$-го типу виконувати бойове завдання $i$-го типу водночас з завданням $r$-го типу, та $\delta_{i j r}=0-$ при неможливості цього);

$\left[t_{0}, T_{3 а д}\right]-$ інтервал часу, на який здійснюється синтез програми розвитку системи озброєння авіації 
ПС ЗС України, від початку реалізації програми $t_{0}$ до іiі завершення $T_{\text {зад; }}$;

$\dot{X}_{r j}(t)$ - похідна за часом функції кількості лі-

таків $j$-го типу, що використовуються для набуття

$r$-ї спроможності, яких треба поставити у війська (темп оновлення парку за рахунок літаків даного $j$ го типу);

$C_{1 j}$ - вартість закупівлі одного серійного зразка літаків $j$-го типу.

$$
\Delta P_{i}\left(T_{\text {зад }}\right) \text { - різниця між необхідним рівнем }
$$
спроможностей та наявним.

Ретельний аналіз (1) показує, що система обмежень та цільова функція такої задачі не враховує можливості нарощення властивостей багатофункціональності перспективних бойових авіаційних комплексів, внаслідок розгляду лише тільки варіантів розподілу наявних сил по бойових завданнях, що співпадають із самою кількістю завдань. Якщо в перспективі очікується поява багатофункціональних літаків, здатних в одному бойовому вильоті виконувати завдання знищення повітряних цілей та нанесення ударів по наземних (надводних) об'єктах, то можлива кількість комбінацій варіантів розподілу наявних сил по завданнях буде набагато більшою. Тому для врахування всіх можливих варіантів такого розподілу пропонується у виразі (1) у відповідних діапазонах зміни значень індексу " $r$ " розширити праву ї межу. Така межа буде дорівнювати сумі числа можливих розміщень двох можливих значень символу $\delta_{i j r}$ (0 або 1) по кількості покладених бойових завдань та двох варіантів, коли зазначений символ приймає значення $\delta_{i j r}=1$ у всіх бойових завданнях для конкретного типу літака (одні й теж самі літаки в змозі приймати участь у виконанні всіх $m$ покладених завдань), або для всіх завдань $\delta_{i j r}=0$

(суто гіпотетичний випадок):

$$
A_{m}^{2}+2=\frac{m !}{(m-2) !}+2 .
$$

Другим недоліком запису формалізованого критерію (1) слід вважати неврахування в ньому впливу на цільову функцію математичної задачі оптимізації потрібних витрат ресурсів на експлуатацію (використання за призначенням та технічне обслуговування) літаків відразу від постачання їх у війська, потрібних для освоєння льотним і інженерно-технічним складом експлуатації нової техніки і озброєння, а також забезпечення льотної підготовки 3 нарощення підготовленості екіпажів до ведення бойових дій (набуття необхідної бойової готовності частин та підрозділів тактичної авіації). Врахування названих витрат може впливати на обрання раціонального варіанту програми оновлення парку бойових літаків. Для усунення такого недоліку пропонується скористатися відомим виразом, наведеним у [12]. Тоді математичний запис задачі синтезу раціональної програми (1) перетвориться у наступну форму запису:

$$
\left\{\begin{array}{l}
\int_{t_{0}}^{T_{\text {зад }}} \sum_{j=1}^{n} K_{\text {БПіj }} \sum_{r=1}^{A_{m}^{2}+2} \delta_{i j r} \dot{X}_{r j}(t) d t \geq \Delta P_{i}\left(T_{\text {зад }}\right), \forall i=1, m ; \\
S=\int_{t_{0}}^{T_{\text {зад }}}\left(\sum_{j=1}^{n}\left[C_{1 j}+\bar{C}_{1 \text { екплj }} \int_{t}^{T_{\text {зад }}} U_{+}(\tau) d \tau\right] \sum_{r=1}^{A_{m}^{2}} \dot{X}_{r j}(t)\right) d t \rightarrow \min ; \\
T_{\text {готі }}(t) \leq T_{\text {зад }},
\end{array}\right.
$$

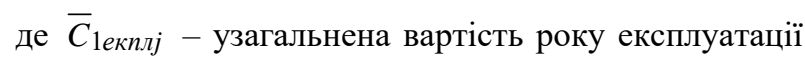
одного літака $j$-го типу; $U_{+}(\tau)-$ одинична асиметрична функція, така, що для поточного часу $\tau, U_{+}(\tau)=$ 0 , при $\tau<t$, та $U_{+}(\tau)=1$, при $\tau \geq t$.

Розв'язання такої задачі у аналітичному вигляді пов'язане із суттєвими труднощами. До того ж, враховуючи той факт, що невідомі, які відшукуються - кількість бойових літаків, які постачатимуться у війська у певний момент часу, за своїм фізичним змістом приймають суто дискретні, а саме позитивні цілі значення, для розв'язування поставленої математичної оптимізаційної задачі (2) доцільно здійснити перехід від інтегралів до інтегральних сум
Рімана. Такий перехід неважко реалізується шляхом розбиття періоду планування $\left[t_{0}, T_{\text {зад}}\right]$ на кінцеву кількість $T$ рівномірних відрізків -інтервалів, тривалістю $\Delta t$ кожен, тобто $T=\frac{T_{\text {зад }}-t_{0}}{\Delta t}$. При цьому, будемо вважати, що постачання нових літаків у війська на кожному інтервалі часу буде відбуватися у середні кожного інтервалу та нові літаки відразу після постачання у військові частини починають використовуватися за призначенням. Тоді формалізований критерій раціональності програми (2) перетворюється у наступну систему виразів: 


$$
\begin{aligned}
& \int \sum_{k=0}^{\mathrm{T}} \sum_{j=1}^{n} K_{\text {БПij }} \sum_{r=1}^{A_{m}^{2}+2} \delta_{i j r} \Delta X_{r j k} \geq \Delta P_{i}\left(T_{3 a \partial}\right), \forall i=\overline{1, m} ;
\end{aligned}
$$

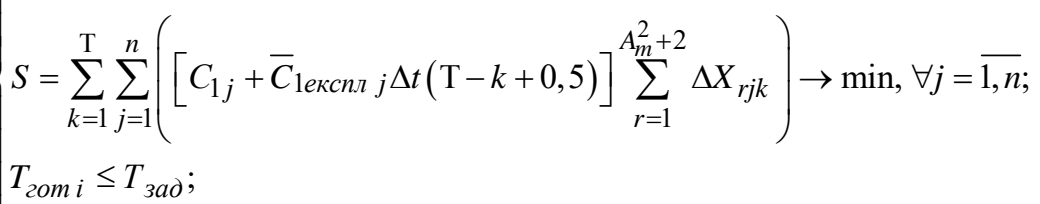

де $\Delta X_{r j k}$ - зміна кількості ЛА j-го типу в парку літаків тактичної авіації на $k$-му інтервалі, за рахунок введення до бойового складу тактичної авіації ПС ЗС України партії нових літаків.

Як було зазначено у роботі [18], для приведення здачі до реальних умов здійснення переозброєння тактичної авіації, у вираз (3) необхідно ввести додаткові обмеження на кількість літальних апаратів, а саме на максимальну кількість літаків, що можуть бути закуплені на визначених інтервалах часу, а також на кількість ЛА, закупка яких є мінімально необхідною на кожному з цих інтервалів. Перше 3 названих обмежень буде пов'язане із обмеженими обсягами серійного виробництва літаків тактичної авіації авіаційною промисловістю (в тому числі, країн-експортерів), а у випадку закупівлі літаків на ринку озброєнь, ще й наявністю або відсутністю у експортерів інших міжнародних домовленостей на поставку багатофункціональних літаків тактичної авіації. Друге додаткове обмеження щодо кількості літаків, мінімальна кількість яких має бути закуплена на визначених інтервалах часу, обумовлено необхідністю поетапного комплектування окремої організаційно-штатної одиниці, підготовки льотчиківінструкторів, льотного та інженерного складу для набуття відповідних навичок у виконанні покладених завдань за призначенням. 3 оглядом на вище зазначене, математична постановка оптимізаційної задачі синтезу раціональної програми оновлення авіаційного парку тактичної авіації за критерієм мінімальних фінансових витрат на всій глибині планування та за умови досягнення необхідного рівня спроможностей буде мати остаточний вигляд:

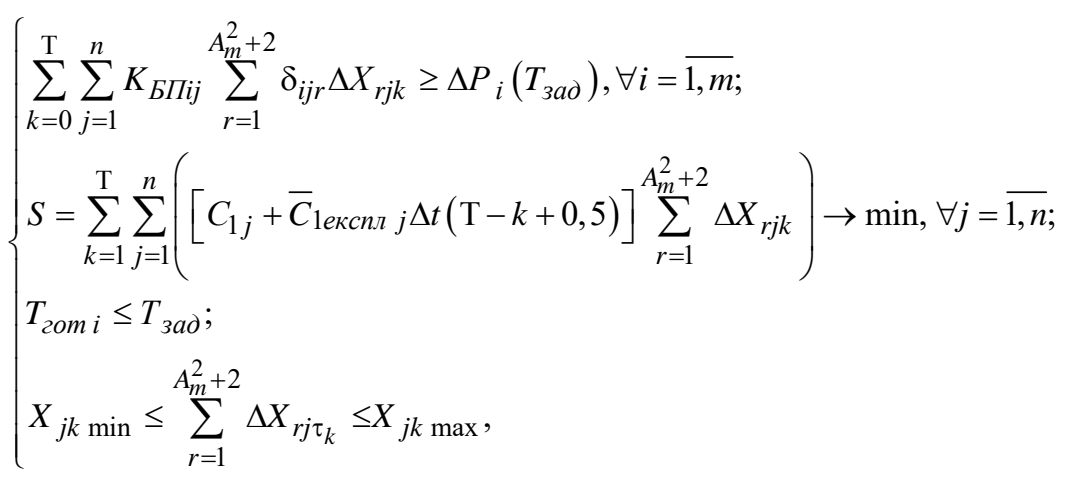

де $X_{j k \min }$ - найменша кількість ЛА $j$-го типу, яку необхідно закупити на $k$-му інтервалі періоду планування;

$X_{j k \text { max }}$ - найбільша кількість ЛА, що може бути поставленою у війська на $k$-му інтервалі часу.

За своєю суттю математична задача синтезу раціональної програми оновлення парку бойових літаків тактичної авіації у постановці виду (4) являє собою канонічну форму запису задачі динамічного управління, рішення якої зводиться до пошуку умовного мінімуму цільового функціоналу чисельними методами багатокрокового програмування [19-21], та для якої існують ефективні алгоритми чисельного розв'язку у програмному забезпеченні сучасних персональних електронно-обчислюваних машин.
3 метою ілюстрації застосування розробленого методичного підходу розглянемо спрощений гіпотетичний приклад синтезу раціональної програми переозброєння авіаційного парку тактичної авіації на глибині планування 15 років із розподілом на три інтервали по п'ять років кожен.

В якості додаткових обмежень на чисельність літаків, що можуть бути поставлені у війська, приймемо наступні:

- на кожному інтервалі планування новими літаками має бути озброєна щонайменше одна авіаційна ескадрилья у складі 12 бойових літаків;

- максимальна кількість літаків, яку спроможна серійно виготовити авіаційна промисловість за рік, складає 12 літаків, тобто на кожному інтервалі часу тривалістю 5 років, максимальна кількість літаків, що може бути поставлена у війська, складає 60 літаків. 
Також приймемо, що бойовими завданнями, у виконанні яких повинні набути спроможності частини та підрозділи тактичної авіації за рахунок переозброєння на новітні багатофункціональні винищувачі, є наступні завдання:

1) відбиття масованого авіаційного удару повітряного противника (пов'язане із знищенням повітряних цілей);

2) нанесення авіаційного удару оперативній глибині побудови противника (пов'язане із знищенням наземних цілей);

3) винищувальне забезпечення дій ударної авіації в ході нанесення авіаційного удару (пов'язане із знищенням повітряних цілей).

Тобто в прикладі прийнята кількість завдань дорівнює $m=3$.

Для розрахунків також приймемо, що необхідний рівень спроможностей, який має набути тактич- на авіація наприкінці терміну планування, становитиме: за першим завданням - еквівалентним застосуванню 120 бойових літаків-еталонів типу МіГ-29, за другим завданням - 40 бойових літаків-еталонів типу Су-24M, а за третім завданням - застосуванню 70 бойових літаків МіГ-29.

В якості альтернативних варіантів обрання типу літаків, при переході системи озброєння тактичної авіації на однотипний парк багатофункціональних літаків [22], розглянемо типи багатоцільових тактичних винищувачів, що на цей час складають основну номенклатуру бойових літаків даного класу на світовому ринку озброєнь. Перелік типів таких літаків та відповідна інформація про значення їх коефіцієнтів бойового потенціалу та економічних показників, необхідна для постановки математичної задачі оптимізації для ілюстративного прикладу, наведена в табл. 1.

Таблиця 1

Альтернативні багатоцільові тактичні винищувачі для переозброєння авіаційного парку тактичної авіації

\begin{tabular}{|c|c|c|c|c|}
\hline \multirow{2}{*}{ Тип ЛА } & \multirow{2}{*}{$\begin{array}{c}\text { Ціна одного } \\
\text { серійного ЛА на } \\
\text { ринку, млн.\$ } \\
\text { (в цінах } 2017 \text { року) }\end{array}$} & \multirow{2}{*}{$\begin{array}{c}\text { Вартість експлуатації } \\
\text { на рік, млн.\$ } \\
\text { (в цінах } 2017 \text { року) }\end{array}$} & \multicolumn{2}{|c|}{ Коефіцієнт бойового потенціалу } \\
\hline & & & $\begin{array}{l}\text { по повітряних цілях } \\
K_{\text {пов }}(\text { еталон МіГ-29) }\end{array}$ & $\begin{array}{c}\text { по наземних цілях } \\
K_{\text {наз }}(\text { еталон Су-24M) }\end{array}$ \\
\hline $\mathrm{F}-16 \mathrm{E}$ & 56 & 2,01 & 0,85 & 1,4 \\
\hline F-35A & 93,3 & 2,51 & 1,73 & 2,27 \\
\hline EF-2000 & 120 & 2,26 & 1,82 & 1,74 \\
\hline Rafale & 85 & 1,94 & 1,64 & 1,67 \\
\hline JAS-39 & 65 & 1,29 & 1,26 & 1,49 \\
\hline
\end{tabular}

Для постановки математичної задачі синтезу раціональної програми переозброєння тактичної авіації складемо спочатку таблицю значень символів $\delta_{i j r}$, які характеризують можливість залучення засобів $j$-го типу до виконання $i$-го бойового завдання та інших бойових завдань із сукупності $m$ завдань водночас, у відповідності до визначеної структури бойового потенціалу авіаційного угруповання. Призначимо символам в таблиці $\delta_{i j r}=1-$ при можливості одним й тим же засобом $j$-го типу

виконувати бойове завдання $i$-го типу водночас 3 завданням $r$-го типу, та $\delta_{i j r}=0-$ при неможливості цього. Тоді загальна кількість можливих варіантів розподілу сил тактичної авіації по завданнях для даного прикладу складає:

$$
A_{m}^{2}+2=\frac{m !}{(m-2) !}+2=\frac{3 !}{(3-2) !}+2=8 .
$$

Можливі значення символів $\delta_{i j r}$ наведені в табл. 3.

Таблиця 3

Можливі значення символів $\delta_{i j r}$

\begin{tabular}{|c|c|c|c|c|c|c|c|c|}
\hline Значення індексів & $r=1$ & $r=2$ & $r=3$ & $r=4$ & $r=5$ & $r=6$ & $r=7$ & $r=8$ \\
\hline$i=1$ & 1 & 1 & 1 & 0 & 0 & 0 & 0 & 0 \\
\hline $\mathrm{i}=2$ & 1 & 1 & 0 & 1 & 0 & 1 & 1 & 0 \\
\hline$i=3$ & 1 & 0 & 1 & 0 & 1 & 1 & 0 & 0 \\
\hline
\end{tabular}

Останній стовпчик табл. 3 для рішення задачі синтезу програми оновлення парку фізичного змісту не несе, та може бути вилученим із подальшого розгляду. Оскільки перше бойове завдання 3 прийнятого переліку завдань буде відокремленим за часом його виконання від виконання другого та третього 
завдання, приймемо, що одні й теж самі засоби в змозі бути залученими до виконання другого та третього завдання. В той же час, друге і третє завдання в даному прикладі виконуватимуться водночас, та залучення одних й теж самих засобів до виконання другого та третього завдань буде залежати від ступеню багатофункціональності окремо взятого засобу. Всі п’ять взятих для ілюстрації типів багатофункціональних винищувачів за притаманними ним властивостями щодо ступеню їх багатофункціональності не в змозі в одному бойовому польоті виконувати винищувальні та ударні задачі, але за показниками бойової готовності (часом підготовки до повторного вильоту) після виконання першого бойового завдання в змозі бути залученими до ви- конання або другого, або третього бойового завдання. Відтоді стовпчики табл. 3 за номерами $r=1$ та $r=6$ можна виключити з розгляду як такі, що не в змозі бути реалізовані для розглянутих альтернативних типів літаків. Стовпчик з номером $r=8$ взагалі немає сенсу для синтезу програми переозброєння, а стовпчики з номерами $r=4, r=5$ та $r=7$ не передбачують залучення тактичної авіації до відбиття масованого нападу повітряного противника, що суперечить умовам прикладу, який розглядається. Тоді табл. 3 можна переписати з вилученням неможливих варіантів та змінюючи, для спрощення, порядок розташування стовпчиків. Табл. 3 перетвориться у наступну таблицю можливих значень відповідних символів:

Таблиця 4

Можливі значення символів $\delta_{i j r}$, з урахуванням ступеню багатофункціональності типів літаків та послідовності виконання завдань

\begin{tabular}{|c|c|c|}
\hline Значення індексів & $r=1$ & $r=2$ \\
\hline$i=1$ & 1 & 1 \\
\hline$i=2$ & 1 & 0 \\
\hline$i=3$ & 0 & 1 \\
\hline
\end{tabular}

Тоді в загальному вигляді математична задача синтезу раціональної програми переозброєння всьо-

го парку тактичної авіації на багатофункціональний літак ј-го типу запишеться наступним чином:

$$
\begin{aligned}
& K_{\text {повј }} \cdot 1 \cdot \Delta X_{1 j 1}+K_{\text {повј }} \cdot 1 \cdot \Delta X_{2 j 1}+K_{\text {повј }} \cdot 1 \cdot \Delta X_{1 j 2}+K_{\text {повј }} \cdot 1 \cdot \Delta X_{2 j 2}+K_{\text {повј }} \cdot 1 \cdot \Delta X_{1 j 3}+K_{\text {повj }} \cdot 1 \cdot \Delta X_{2 j 3} \geq 120 \text {; } \\
& K_{\text {назј }} \cdot 1 \cdot \Delta X_{1 j 1}+K_{\text {назј }} \cdot 0 \cdot \Delta X_{2 j 1}+K_{\text {назј }} \cdot 1 \cdot \Delta X_{1 j 2}+K_{\text {назј }} \cdot 0 \cdot \Delta X_{2 j 2}+K_{\text {назј }} \cdot 1 \cdot \Delta X_{1 j 3}+K_{\text {назј }} \cdot 0 \cdot \Delta X_{2 j 3} \geq 40 \\
& K_{\text {повј }} \cdot 0 \cdot \Delta X_{1 j 1}+K_{\text {пов }} \cdot 1 \cdot \Delta X_{2 j 1}+K_{\text {повј }} \cdot 0 \cdot \Delta X_{1 j 2}+K_{\text {пов }} \cdot 1 \cdot \Delta X_{2 j 2}+K_{\text {nовj }} \cdot 0 \cdot \Delta X_{1 j 3}+K_{\text {nовј }} \cdot 1 \cdot \Delta X_{2 j 3} \geq 70 \text {; }
\end{aligned}
$$

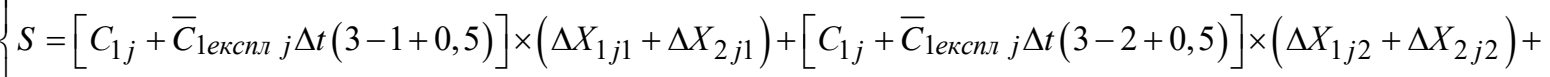

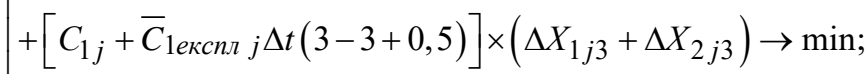

$$
\begin{aligned}
& T_{\text {гоm } i} \leq 15 \text {; } \\
& 12 \leq\left(\Delta X_{1 j 1}+\Delta X_{2 j 1}\right)+\left(\Delta X_{1 j 2}+\Delta X_{2 j 2}\right)+\left(\Delta X_{1 j 3}+\Delta X_{2 j 3}\right) \leq 60 .
\end{aligned}
$$

Результати розв'язку поставленої математичної задачі синтезу раціональної програми переозброєння парку тактичної авіації на глибині планування 15 років із розподілом на визначені інтервали часу всього періоду планування із забезпеченням досягнення прийнятого в прикладі необхідного рівня спроможностей для виконання завдань наведено у табл. 5.

\begin{tabular}{|c|c|c|c|c|c|}
\hline \multirow{3}{*}{ Тип ЛА } & $\Delta t=5$ років & $\Delta t=5$ років & $\Delta t=5$ років & \multirow{3}{*}{$\begin{array}{c}\text { Загальна } \\
\text { кількість } \\
\text { ЛА }\end{array}$} & \multirow{3}{*}{$\begin{array}{c}\text { Загальна вартість } \\
\text { програми } \\
\text { переозброєння } \\
\text { (млн.\$, в цінах } \\
2017 \text { року) }\end{array}$} \\
\hline & $\tau=1$ & $\tau=2$ & $\tau=3$ & & \\
\hline & \multicolumn{3}{|c|}{$\begin{array}{c}\text { Кількість ЛА (од.) за інтервалами та витрати } \\
\text { на закупівлю і експлуатацію (млн.\$, в цінах } 2017 \text { року) }\end{array}$} & & \\
\hline \multirow{4}{*}{ F-16E } & 22 & 60 & 60 & \multirow{4}{*}{142} & \multirow{4}{*}{9781,825} \\
\hline & \multicolumn{3}{|l|}{1784,8} & & \\
\hline & & \multicolumn{2}{|l|}{4335,6} & & \\
\hline & & & 3661,5 & & \\
\hline
\end{tabular}

Таблиця 5

Синтезовані програми переозброєння тактичної авіації на однотипний парк бойової авіаційної техніки для альтернативних типів літаків 
Закінчення табл. 5

\begin{tabular}{|c|c|c|c|c|c|}
\hline \multirow{4}{*}{ F-35 } & 12 & 12 & 46 & \multirow{4}{*}{70} & \multirow{4}{*}{7425,6} \\
\hline & \multicolumn{3}{|l|}{1497,6} & & \\
\hline & & \multicolumn{2}{|l|}{1346,4} & & \\
\hline & & & 4581,6 & & \\
\hline \multirow{4}{*}{ EF-2000 } & 12 & 12 & 43 & \multirow{4}{*}{67} & \multirow{4}{*}{8825,35} \\
\hline & 1779 & & & & \\
\hline & & 1643,4 & & & \\
\hline & & & 5402,95 & & \\
\hline \multirow{4}{*}{ Rafale } & 12 & 13 & 50 & \multirow{4}{*}{75} & \multirow{4}{*}{9935} \\
\hline & 1816,5 & & & & \\
\hline & & 1804,7 & & & \\
\hline & & & 6313,8 & & \\
\hline \multirow{4}{*}{ JAS-39 } & 12 & 24 & 60 & \multirow{4}{*}{96} & \multirow{4}{*}{6856,8} \\
\hline & 972,75 & & & & \\
\hline & & 1791,3 & & & \\
\hline & & & 4092,75 & & \\
\hline
\end{tabular}

Якщо розглядати перший інтервал часу гіпотетичного переозброєння тактичної авіації, зокрема на літаки JAS-39, обсяг першої закупівлі має скласти 12 одиниць. Орієнтовна вартість такої угоди із врахуванням подальшої експлуатації закуплених літаків (умовно передбачено врахування фінансових витрат на експлуатацію нових літаків із середини інтервалу, на якому здійснюється закупівля усієї запланованої партії літаків) становитиме 972,75 млн.\$ (в цінах 2017 року). У разі залучення тактичної авіації для виконання завдань за визначеними сценаріями на першому етапі переозброєння нові літаки доцільно залучати для вирішення як винищувальних, так i ударних задач, що пов'язані із знищенням наземних та надводних цілей.

На другому інтервалі часу з періоду планування - має бути закуплено 24 багатофункціональних тактичних винищувача. Орієнтовна вартість такої угоди із врахуванням витрат на експлуатацію становитиме 1791,3 млн.\$ (в цінах 2017 року). У цьому випадку 9 бойових літаків доцільно спрямувати на нарощування спроможностей тактичної авіації у винищувальних бойових завданнях (прикриття військ та важливих об'єктів, відбиття масованих авіаційних ударів противника, винищувального забезпечення дій інших родів авіації), а 15 бойових літаків залучати до вирішення як винищувальних, так і ударних задач з відповідною підготовкою необхідної кількості екіпажів.

На третьому інтервалі часу планова закупівля складатиме 60 літаків. Орієнтовна вартість такої угоди із врахуванням експлуатаційних витрат становитиме 4092,75 млн.\$ (в цінах 2017 року). Придбані на цьому інтервалі планування бойові літаки доцільно спрямувати на нарощування спроможностей тактичної авіації у виконанні завдань відбиття масованого авіаційного удару та винищувального забезпечення авіаційного удару.

Таким чином, у разі гіпотетичного переозброєння тактичної авіації на багатофункціональний тактичний винищувач JAS-39, загальний необхідний обсяг закупівлі літаків такого типу складатиме 96 бойових одномісних літаків та 16 двомісних навчально-бойових літаків типу JAS-39. Якщо за орієнтовну вартість літака на світовому ринку озброєння та витрати на його експлуатацію на протязі одного року взяти ціни 2017 року, що складають 65млн. \$ та 1,285 млн. \$, відповідно, то орієнтовні загальні витрати на переозброєння парку тактичної авіації на літак JAS-39 складатимуть 6869,65 млн. \$ на глибині планування у 15 років.

Якщо у якості альтернативного варіанту переозброєння парку тактичної авіації розглядати літак F-16E, то при дотриманні аналогічних обмежень щодо розподілу програмного періоду на інтервали та обсягу мінімальних закупок із забезпеченням необхідного рівня спроможностей для виконання завдань, орієнтовна вартість такої програми переозброєння на глибині планування 15 років складатиме 9781,825 млн. \$. Таке значне розходження у загальних фінансових витратах обумовлено різницею в значеннях коефіцієнту бойового потенціалу літака F-16Е, який по повітряних цілях на 32,5\% та по наземних цілях на $6,1 \%$, гірший ніж відповідних показників бойових властивостей літака типу JAS39. Це вимагає для набуття необхідних спроможностей тактичною авіацією закупівлі більшої кількості літаків, а саме - 142 одиниці (без врахування потреби у навчально-бойових варіантах літаків).

Таким чином, в якості раціональної програми переозброєння авіаційного парку тактичної авіації терміном на 15 років для прикладу, що розглядається, із розподілом на три інтервали часу періоду планування, тривалістю по 5 років кожний, доцільно 
обрати програму переозброєння на літаки JAS-39 із забезпеченням закупівлі по інтервалах: 12 одиниць на першому, 24 одиниць - на другому та 60 літаків на третьому інтервалі часу. Можливий перерозподіл обсягів закупівлі літаків за інтервалами розподілу планового періоду призведе до збільшення сумарних фінансових витрат на всій глибині планування.

Таким чином, запропонований методичний підхід дозволяє здійснити синтез раціональної програми переозброєння тактичної авіації на нові літаки, навіть з будь якою деталізацією за часом при наявності кондиційних вхідних даних для постановки задачі оптимізації.

\section{Висновки}

Запропоновано методичний підхід до розв'язання математичної задачі синтезу раціональної програми розвитку системи озброєння та військової техніки тактичної авіації, постановку якої здійснено у зворотній формі за критерієм мінімальних фінансових витрат на всій глибині планування оновлення парку тактичної авіації за умови досягнення перспективним складом тактичної авіації необхідного рівня спроможностей для виконання завдань за визначеними сценаріями застосування.
Такий методичний підхід вирізняється від відомих можливістю врахування усіх варіантів застосування тактичних літаків конкретного типу, що можуть бути залучені до виконання завдань за визначеними сценаріями застосування тактичної авіації з урахуванням притаманних цьому типу літака властивостей багатофункціональності.

Обгрунтовано введення додаткових обмежень, пов'язаних, по-перше, із можливостями серійного виготовлення нових літаків авіаційною промисловістю за максимальними темпами виробництва, подруге, необхідністю закупівлі достатньої кількості літаків на кожному інтервалі періоду планування для забезпечення освоєння нової техніки особовим складом та доведення частин і підрозділів тактичної авіації до заданого рівня бойової готовності.

Задачу синтезу програми зведено до канонічної форми пошуку умовного мінімуму цільової функції відомими методами багатокрокового програмування.

Подальші дослідження планується спрямувати на розробку методичного підходу до розв'язання математичної задачі синтезу програми розвитку системи озброєння тактичної авіації за стратегію швидкої ліквідації нестачі спроможності за мінімально можливий час.

\section{Список літератури}

1. Указ Президента України від 04.06.2016 року № 240/2016 “Про рішення Ради національної безпеки і оборони України від 20.05.2016 “Про Стратегічний оборонний бюлетень України”.

2. Указ Президента України від 26.05.2015 року № 287/2015 “Про рішення Ради національної безпеки і оборони України від 06.05.2015 “Про Стратегію національної безпеки України”.

3. Указ Президента України від 14.03.2016 року № 92/2016 "Про рішення Ради національної безпеки і оборони України від 04.03.2016 “Про Концепцію розвитку сектору безпеки і оборони України”.

4. Оборонне планування на основі спроможностей: особливості та перспективи впровадження / I. Руснак, А. Петренко, А. Яковенко, І. Романюк, В. Кохно // Наука і оборона. - 2017. - № 2. - С. 3-10.

5. Рекомендації з оборонного планування на основі спроможностей в Міністерстві оборони України та Збройних Силах України: затверджено Міністром оборони України, 12 червня 2017 року / Міністерство оборони України (Департамент воєнної політики, стратегічного планування та міжнародного співробітництва Міністерства оборони України). K.:MOУ, 2017. $-29 \mathrm{c}$.

6. Руснак І.С. Розвиток методологічних положень обгрунтування заходів організаційного будівництва (реформування) Повітряних Сил ЗС України / І.С. Руснак, О.М. Загорка // Наука і оборона. - 2010. - № 1. - С. 6-12.

7. Чепков І.Б. Основні аспекти методології формування та супроводження реалізації середньострокових програм озброєння в умовах особливого періоду / І.Б. Чепков М.І. Луханін, І.В. Борохвостов // Озброєння та військова техніка. 2016. - № 4(2). - С. 3-8.

8. Системная методология планирования развития, предпроектных исследований и внешнего проектирования вооружения и военной техники / Б.А. Демидов, М.И. Луханин, А.Ф. Величко, М.В. Науменко; под ред. Б.А. Демидова. - К.: Стилос, 2011. - 464 с.

9. Оборонна реформа: системний підхід до оборонного менеджменту: монографія / А. Павліковський, В. Фролов, Ф. Саганюк та ін.; за заг. ред. А. Сиротенка. - Київ: НУОУ, 2020. - 274 с.

10. Оборонний огляд: український вимір 2014-2018: монографія / Ф. Саганюк, А. Павліковський, П. Щипанський та ін.; за заг. ред. І. Руснака. - Київ: МО та ГШ ЗС України, НУОУ, 2019. - 196 с.

11 Борохвостов І.В. Визначення критеріїв та методів оцінювання шляхів забезпечення військових формувань озброєнням та військовою технікою / І.В. Борохвостов, М.О. Білокур // Озброєння та військова техніка. - 2018. № 3(19). - С. 3-8.

12. Сучасний метод бойових потенціалів в прикладних задачах планування розвитку та застосування тактичної авіації: монографія / Б.Й. Семон, О.Б. Леонтьєв та ін. - К.: НАОУ, 2009. - 336 с. 
13. Котов О.Б. Обгрунтування вибору критеріїв раціональності кількісно-якісного складу повітряної компоненти міжвидового збройного угруповання / О.Б. Котов, І.С. Романченко // Збірник наукових праць ХУПС. - 2012. - № 3(9). C. 14-17.

14. Дроздов С.С. Методика постановки та розв'язування зворотної задачі оптимізації бойового (кількісно-якісного) складу тактичної авіації і зенітних ракетних військ перспективних Повітряних Сил / С.С. Дроздов, О.Б. Леонтьєв // Наука і техніка Повітряних Сил Збройних Сил України. - 2017. - № 2(27). - С. 7-14. https://doi.org/10.30748/nitps.2017.27.01.

15. Формування порядку воєнно-економічного оцінювання результатів виконання заходів та програм розвитку Збройних Сил України / Р.В. Бойко, О.М. Семененко, О.І. Кремешний, І.М. Чернишова // Системи озброєння і військова техніка. - 2011. - № 3(27). - С. 98-101.

16. Метод оцінювання ефективності виконання програм (планів) розвитку Збройних Сил України з урахуванням повноти та своєчасності їх фінансування / О.М. Семененко, О.Г. Водчиць, Л.М. Семененко, Р.В. Бойко, Д.В. Башинський, Г.Г. Зубрицька // Збірник наукових праць Харківського національного університету Повітряних Сил. - 2017. - № 2(51). - C. 51-58. https://doi.org/10.30748/zhups.2017.51.10.

17. Леонтьєв О.Б. Напрями удосконалення науково-методичного апарату обгрунтування основних напрямів розвитку системи озброєння авіації Повітряних Сил Збройних Сил України / О.Б. Леонтьєв, М.В. Науменко // Наука і техніка Повітряних Сил Збройних Сил України. - 2020. - № 3(40). - С. 69-78. https://doi.org/10.30748/nitps.2020.40.08.

18. Дроздов С.С. Формалізовані критерії раціональності програми розвитку системи озброєння тактичної авіації Повітряних Сил Збройних Сил України на довгостроковій перспективі (прогнозованій) загрозі / С.С. Дроздов, О.Б. Леонтьєв, М.В. Науменко // Збірник наукових праць Харківського національного університету Повітряних Сил. - 2020. - № 3(65). - C. 13-24. https://doi.org/10.30748/zhups.2020.65.02.

19. Сухарев А.Г. Курс методов оптимизации / А.Г. Сухарев, А.В. Тимохов, В.В. Федоров. - М.: Наука, 1986. - 328 с.

20. Мину М. Математическое программирование. Теория и алгоритмы: Пер. с фр. под ред. А.И. Штерна / М. Мину. - М.: Наука, 1990. - 488 c.

21. Банди Б. Основы линейного программирования: пер. с англ. / Б. Банди. - М.: Радио и связь, 1989. - 176 с.

22. Візія Повітряних Сил 2035. - Вінниця: Командування Повітряних Сил Збройних Сил України, 2020. - 42 с.

Надійшла до редколегії 18.08.2020

Схвалена до друку 15.09.2020

\section{Відомості про авторів:}

Дроздов Сергій Семенович кандидат військових наук Командувач Повітряних Сил Збройних Сил України, Вінниця, Україна https://orcid.org/0000-0001-9704-4023

Леонтьсв Олексій Борисович доктор технічних наук професор головний науковий співробітник Харківського національного університету Повітряних Сил ім. І. Кожедуба, Харків, Україна https://orcid.org/0000-0003-4003-7759

Науменко Марина Володимирівна кандидат технічних наук старший науковий співробітник провідний науковий співробітник

Харківського національного університету

Повітряних Сил ім. І. Кожедуба,

Харків, Україна

https://orcid.org/0000-0002-1216-9263

\section{Information about the authors:}

\section{Serhii Drozdov}

Candidate of Military Sciences

Commander of the Air Force

of the Armed Forces of Ukraine,

Vinnytsia, Ukraine

https://orcid.org/0000-0001-9704-4023

Oleksii Leontiev

Doctor of Technical Sciences Professor

Chief Research

of Ivan Kozhedub Kharkiv

National Air Force University,

Kharkiv, Ukraine

https://orcid.org/0000-0003-4003-7759

\section{Maryna Naumenko}

Candidate of Technical Sciences Senior Research

Lead Research

of Ivan Kozhedub Kharkiv

National Air Force University,

Kharkiv, Ukraine

https://orcid.org/0000-0002-1216-9263

\title{
МЕТОДИЧЕСКИЙ ПОДХОД К РЕШЕНИЮ МАТЕМАТИЧЕСКОЙ ЗАДАЧИ СИНТЕЗА РАЦИОНАЛЬНОЙ ПРОГРАММЫ РАЗВИТИЯ СИСТЕМЫ ВООРУЖЕНИЯ ТАКТИЧЕСКОЙ АВИАЦИИ НА ОСНОВЕ КРИТЕРИЯ МИНИМИЗАЦИИ ФИНАНСОВЫХ ЗАТРАТ ПРИ УСЛОВИИ ДОСТИЖЕНИЯ НЕОБХОДИМЫХ БОЕВЫХ ВОЗМОЖНОСТЕЙ
}

\author{
С.С. Дроздов, А.Б. Леонтьев, М.В. Науменко
}

Предложен методический подход к решению математической задачи синтеза рациональной программы развития системы вооружения тактической авиации, постановка которой осуществлена в обратной форме, при выборе в качестве критерия рациональности программы достижения необходимого заданного уровня боевых возможностей 
частями и подразделениями тактической авиации за заданный период времени при минимально необходимых финансовых затратах. Задача синтеза программы сведена к канонической форме поиска условного минимума иелевой функции известными методами многошагового программирования. Обосновано введение дополнительных ограничений, связанных, во-первых, с возможностями обеспечения максимального темпа серийного производства новых самолетов авиационной промышленностью, а во-вторых, необходимостью закупки минимального количества новой авиационной техники для обеспечения освоения новых типов самолетов личным составом и доведения авиационных частей и подразделений до боеготового состояния.

Ключевые слова: планирование на основе возможностей, критерии рациональности, оптимизация, программа развития, система вооружения тактической авиации.

\section{METHODOLOGICAL APPROACH TO SOLVING THE MATHEMATICAL PROBLEM OF SYNTHESIS OF RATIONAL PROGRAM FOR THE DEVELOPMENT OF THE TACTICAL AVIATION WEAPONS SYSTEM BASED ON THE CRITERION OF MINIMIZING FINANCIAL COSTS UNDER THE CONDITIONS OF ACHIEVING THE REQUIRED COMBAT CAPABILITIES}

S. Drozdov, O. Leontiev, M. Naumenko

A methodological approach to solving the mathematical problem of synthesis of rational program for the development of the tactical aviation weapons system is proposed. The approach is based on the use of criterion that determines as rational that version of the program for the development of the tactical aviation weapons system, in which the achievement of the required predetermined level of combat capabilities by tactical aviation units and subunits for given period of time requires the minimum necessary financial costs. Formalization of the dependence of the increase in the combat capabilities of tactical aviation units and subunits due to the supply of new combat aircraft to the troops is carried out using modified method of combat potentials. The objective function of the mathematical optimization problem takes into account the costs of purchasing batch of new aircraft and the generalized costs of their operation, both flight and technical. The problem of finding the conditional minimum of the objective function is proposed to be solved by multi-step programming methods. The entire planning period for the development of the tactical aviation weapons system is proposed to be divided into finite number of uniform intervals, in which unknown number of new aircraft to be supplied to the troops is sought. Accounting for the operating costs of new aircraft for each time interval occurs on the condition that batch of aircraft arrives at the troops in the middle of this time interval and is immediately put into operation.

As additional restrictions, restrictions are used, connected, firstly, with the possibilities of ensuring the maximum rate of serial production of new aircraft by the aviation industry, and secondly, the need to purchase minimum amount of new aviation equipment to ensure the development of new aircraft by personnel and bring aviation units and subdivisions to a combat readiness state.

To illustrate the application of the proposed methodological approach to solving practical problems, simplified hypothetical example of the synthesis of rational program for rearmament of tactical aviation in the fifteen year perspective is considered. The example assumes that promising fleet of multifunctional tactical fighters will consist of aircraft of the same type. Five modern tactical fighters are considered as alternative types, and variants of rational programs for their delivery to the troops in three periods of time, each lasting five years, are synthesized. The comparative analysis of the synthesized rational rearmament programs is carried out and the difference in the required volumes of financial costs for their implementation is estimated when prices are fixed for all alternatives within the same financial year.

Keywords: capability-based planning, rationality criteria, optimization, development program, tactical aviation weapons system. 